\title{
FACTORS INFLUENCING THE EXTENT OF CORPORATE COMPLIANCE WITH IFRS. THE CASE OF HUNGARIAN LISTED COMPANIES
}

\author{
Lecturer PhD Szilveszter Fekete, „Babeş-Bolyai” University of Cluj-Napoca, \\ e-mail: szilveszter.fekete@econ.ubbcluj.ro \\ Pofessor PhD Dumitru Matiş, „Babeş-Bolyai” University of Cluj-Napoca, \\ e-mail:dumitru.matis@econ.ubbcluj.ro \\ Professor PhD János Lukács, „,Corvinus” University of Budapest, \\ e-mail:janos.lukacs@uni-corvinus.hu
}

\begin{abstract}
Since 2005 European listed companies report their financial figures based on IFRSs. This paper investigates whether Hungarian listed companies comply with IFRS disclosure requirements, identifying some factors associated with the level of compliance. Although the issue of consolidation is not a new topic for Hungarian specialists, the analysis focuses on the disclosure aspects of consolidation because publishing consolidated accounts is considered still a problematic field (Fekete, 2008).

Findings suggest that corporate size and industry type (more specifically being in the IT\&C sector) are statistically associated with the extent of compliance with IFRS disclosure requirements. This suggest that big, high tech companies comply best to IRFS rules, possibly because they can benefit the most from them.
\end{abstract}

Keywords: IAS/IFRS, compliance, disclosure, Hungary

JEL Codes: M40, M41

\section{Motivation and objectives}

The most important change in the field of accounting in European countries is that according to EC Regulation no. 1606/2002 on the application of international accounting standards, listed companies must apply IFRS rules starting from financial year 2005 in their financial reporting system.

This change affected Hungary also, since the country gained membership already in 2004, therefore it had to implement IFRS in the domestic accounting regulation. This problem was solved by changing the Law on Accounting no. 100/2000 in 2004 (Law 99/2004 on changes in accounting legislation) therefore increasing international harmonization with EU law and beyond (Borbély and Evans, 2006).

The paper aims to analyze the empirical aspects of IFRS application. There is (already) a vast literature on the economic effects/consequences of IFRS adoption (voluntary and mandatory) and application, the most recent and thorough paper about Europe being Daske et al., 2008 ${ }^{1}$. My focus is on the extent of compliance with IFRS requirements concerning disclosure matters of Hungarian listed companies. Furthermore we investigate which company specific characteristics are associated with level of disclosure.

\footnotetext{
${ }^{1}$ An excellent synthesis of these consequences has been presented by prof. Bernard Raffournier in AMIS 2008 Bucharest plenary session speech entitled "The implementation of IFRSs in Europe: The preliminary evidence" (http://cig.ase.ro/amis2008/?1=en\&lin=2000\&idart=265)
} 
However, researching disclosure compliance for each standard (IAS and IFRS) exceeds our work capacity, and some ceteribus paribus is needed. This is why we focus in this paper exclusively on the consolidation requirements of IFRSs, the objective of the paper being to determine the extent of compliance of Hungarian companies with IFRS rules in consolidation disclosure.

The paper is organized as follows. In the next chapter we present a short review of the growing literature which is important is setting the context of the study as well as the hypotheses. This is followed by discussion of methodology of research. In chapter 4 findings are critically evaluated and then the conclusions chapter closes the paper.

\section{Research framework, literature review and development of hypotheses}

IFRS disclosure compliance literature can be considered as part of disclosure research (Fekete, 2008). Since companies disclose information on both mandatory and voluntary basis, information that is produced in reference with a GAAP applied whether on mandatory or voluntary basis, we must therefore set a framework for these studies in order to understand the implication of their findings. I propose therefore the following framework:

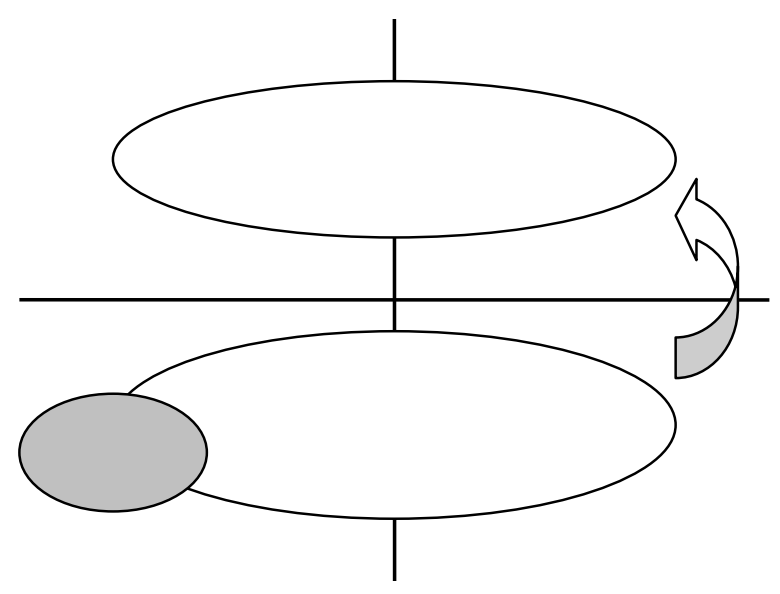

Fig. nr. 1 - Framework for IFRS disclosure research

According to this two dimensions of disclosure research are fundamental: the basis on which disclosure is provided, i.e. the way as companies apply IFRS (voluntary or mandatory) and the information content of disclosure, that can be regulated (mandatory since IFRS rules require them) or voluntary (exceed IFRS requirements). Thus voluntary disclosure research must be separated from mandatory disclosure research (also referred as disclosure compliance research). There is also a link between them, as the volume of information required by IFRS increases, and therefore mandatory disclosure shifts towards voluntary disclosure, and disclosure compliance research incorporates more and more topics from its voluntary disclosure peer.

As previously mentioned, the research landscape in Europe has been significantly changed by the decision of European Council to adopt IFRS for European listed companies. This means that entities which produced both voluntary and mandatory disclosure on voluntary IFRS application basis, they will be required to publish accounting figures, therefore the research shifts to voluntary and mandatory disclosure on mandatory IFRS application basis. This study is positioned in the mandatory-mandatory cell, since Hungarian companies are required to report under IFRS and the 
focus is on the level of compliance with IFRS requirements. The other methodological aspects are discussed in Chapter 3. A short review of the previous studies in this 'mandatory-mandatory' dimension is carried out in the following part of this chapter.

Although IASB (through its predecessor IASC) operates since 1973, strange to say investigations on the compliance with its requirements appeared much later. An explanation to this bizarre delay could be that IAS/IFRS rules that time were adopted exclusively on voluntary basis.

As we all know artificial languages cannot survive, since they lack cultural underpinning, such as the case of Esperanto language. It was strongly debated whether an 'international language of accounting', i.e. IAS/IFRS can make it on long term (Fearnley and Sunder, 2006). This triggered the first studies that questioned whether International Accounting Standards (IASs) are enforceable (Glaum and Street, 2003).

The early research shows that companies or even countries adopt IFRS voluntarily because they can benefit from adoption. The first such study was carried out by Dumontier and Raffournier (1998) on Swiss data, who showed a positive influence of size, internationality, listing status, auditor type and ownership diffusion on voluntary compliance with IAS, but they found no significant relationship for leverage, profitability and capital intensity. Therefore they revealed that firms which comply with IAS are larger, more internationally diversified, less capital intensive and have a more diffuse ownership. These lead to the conclusion that political costs and pressures from outside markets play a major role in the decision to apply IAS, but they do not validate the hypothesis that voluntary compliance is used to solve monitoring problems between managers, shareholders and creditors.

Another seminal paper belongs to Hope et al. (2006) in which the authors empirically documented that countries with weaker investor protection mechanisms are more likely to adopt IFRS, and therefore concluded that IFRS represent a vehicle through which countries can improve investor protection and make their capital markets more accessible to foreign investors.

Research in disclosure level and compliance with IAS/IFRS began around the year of 2000 and showed a great deal of non-compliance with IAS requirements in various fields (Cairns, 1999; El-Gazzar et al., 1999; Street et al., 1999; Tower et al., 1999). Later studies focus on cross-listed companies seeking to identify significant differences between US listed (and also filing is US) and non-us listed companies. Findings indicate that the overall level of disclosure is greater for companies with US listings (Street and Bryant, 2000; Glaum and Street, 2003).

A more thorough study, that analyzed the factors influencing IAS compliance belongs to Street and Gray (2002). The authors in their monograph used an international sample of 279 firms and tested several variables against the level of disclosure such as listing status, company size, profitability, industry, notes on the accounts, type of auditor, country, multinationality, size of home stock market. All relevant IASs in force have been considered in the construction of the disclosure level index, extending significantly the scope and relevance of the variable. Findings suggest, that there is a significant extent of non-compliance with IAS. Further, as regards factors associated with compliance with IAS disclosure requirements, there is a significant positive association with a U.S. listing/filing and/or non-regional listing, being in the commerce and transportation industry, referring exclusively to the use of IAS, being audited by a Big $5+2$ firm, and being domiciled in China or Switzerland. Additionally, there is a significant negative association with being domiciled in France, Germany, or other Western European countries. Other studies that documented problems in IAS/IFRS compliance are Taplin et al. (2002) in six Asia Pacific countries, Dahawy et al. (2002) in Egipt and Joshi and Al-Mudhahki (2001) in Bahrain.

Unfortunately there is a total dearth of such studies and evidence in Central and Eastern European countries, particularly to Hungary and Romania except for those that have been carried out using an international sample, such as Street and Gray $(2002)^{2}$. This paper therefore is the first

\footnotetext{
${ }^{2}$ According to the sample description, 6 Hungarian listed companies have been included (Street and Gray, 2002, p. 58).
} 
empirical study carried out on Hungarian data and contributes to understanding the level of compliance with IFRS disclosure requirements and its determinants.

As previously mentioned, IAS/IFRS disclosure compliance literature can be considered as part of disclosure research. This can be easily acknowledged if we take a look on the research techniques applied (hypotheses tested and methodology used). Literature is abundant of studies that address the impact of corporate and (more recently) governance characteristics on disclosure level or quality - measured as an index (Cerf, 1961; Singhvi and Desai, 1971; Belkaoui and Kahl, 1978; Chow and Wong-Boren, 1987; Cooke, 1989, 1991; Wallace et al., 1994; Wallace and Naser, 1995; Meek et al., 1995; Inchausti, 1997; Dumontier and Raffournier, 1998). There are other studies that focus on the consequences of the disclosure (Leuz and Verrechia, 2000). Healy and Palepu, 2001 provides an excellent review of the empirical disclosure literature. These authors may focus on the overall level of disclosure or on the level of compliance with a certain set of standards. The methodology applied is usually based on the disclosure index developed by Cooke (1989, 1991, 1992) as discussed in the next chapter.

Based on previous studies the current research uses the most frequent and significant determinants applied in the literature, also making use of the results obtained, the hypotheses proposed for testing being the following:

$H_{1}$ : Company size is positively associated with the level of compliance with IFRS disclosure requirements of Hungarian companies.

$\mathrm{H}_{2}$ : Profitability is positively associated with the level of compliance with IFRS disclosure requirements of Hungarian companies.

$H_{3}$ : Leverage is associated with the level of compliance with IFRS disclosure requirements of Hungarian companies.

$H_{4}$ : Auditor type is positively associated with the level of compliance with IFRS disclosure requirements of Hungarian companies.

$H_{5}$ : Listing status (cross listings) is positively associated with the level of compliance with IFRS disclosure requirements of Hungarian companies.

$H_{6}$ : International visibility is positively associated with the level of compliance with IFRS disclosure requirements of Hungarian companies.

$H_{7}$ : Type of industry is associated with the level of compliance with IFRS disclosure requirements of Hungarian companies.

Although leverage and industry type are considered problematic in the literature because of the mixed results obtained in different studies, we choose to include them in this research since the issue of leverage is very important for Hungarian companies, many of them having high gearing. International visibility is employed more often in case of internet disclosure/reporting studies (Debreceny et al., 2002; Oyelere et al., 2003; Raffournier, 2003; Marston and Polei, 2004; Fekete et al., 2008), its current use as a determinant of disclosure compliance can be considered premier.

\section{Methodological issues of the research}

In this chapter of 'methodological issues' we discuss both data collection (sample and variable definition) and analysis (econometric model, tests applied).

Hungarian stock market (Budapesti Értéktőzsde, Budapest Stock Exchange; BÉT) is a relatively small market compared to its other west European, American or Asian counterparts. It currently comprehends 42 entities out of which 22 are A tier listed (blue chips) and 20 belong to tier B. I considered for the study only A tier companies listed on December 31, 2006 due to reporting considerations $^{3}$, from which we excluded some because of their particularities, i.e. banks.

\footnotetext{
${ }^{3}$ These companies are the Hungarian blue chips, therefore these are the most relevant for the study. Financial year 2006
} 


\section{Sample description}

Table no. 1

\begin{tabular}{cc}
\hline & Number of entities \\
\hline Hungarian A tier listed companies at the end of $2006^{4}$, less & 21 \\
- Financial institutions (banks) & -2 \\
\cline { 2 - 2 } Companies in non-financial sector, less & 19 \\
- Companies with no available financial information & 0 \\
- Companies excluded for data management reasons & 1 \\
\cline { 2 - 2 } Companies included in the sample & 18 \\
\hline
\end{tabular}

The design of the dependent variable is based on the disclosure index proposed by Buzby (1975, p.27, cited by Cooke, 1989) and further developed by Cooke (1989, 1998). This index compares the actual disclosure with total possible disclosure on a certain standard:

$$
D I=\frac{\sum_{i=1}^{m} d_{i}}{\sum_{i=1}^{n} d_{i}}
$$

where:

$D I \quad=$ disclosure index;

$d_{i} \quad=$ index item $i, 1$ if the information (item) is supplied (disclosed) and 0 otherwise;

$m \quad$ number of items actually presented;

$n \quad=$ number of total possible items that apply.

It is obvious that if the value of the index approaches to 1 the level of disclosure and compliance is higher (the entity provides more information) and the compliance is more satisfactory, until $D I=1$, in case of which we speak about full compliance.

Taking in consideration the objective of the study (i.e. disclosure compliance concerning consolidation), we took in consideration in the design of the index the following standards: IFRS 3 Business Combinations, IAS 27 Consolidated and Separate Financial Statements, IAS 28 Investments in Associates, and IAS 31 Interests in Joint Ventures, all being updated and due on January $1,2006^{5}$. In the definition of the index items Deloitte IFRS presentation and disclosure checklist was used (Deloitte, 2006). Finally, the mathematical form of the index is:

where:

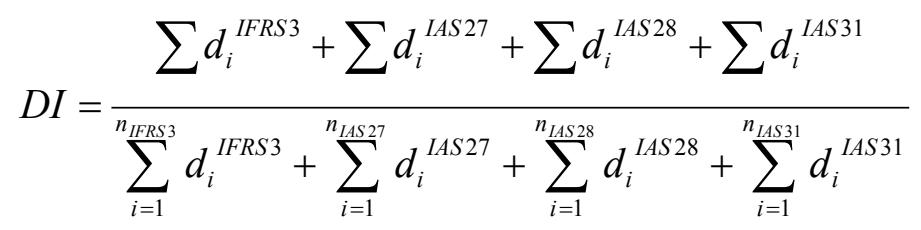

$D I=$ disclosure index;

was chosen because the study was part of my doctoral thesis elaborated in the first semester of 2008, hence data for 2007 being unavailable.

${ }^{4}$ It is important to mention that at the end of year 2006 only 19 companies have been actually listed on BÉT. I included the others two because they were listed later in 2007 but they provided all the financial information as other already listed companies, i.e. certified consolidated financial statements for financial year 2006. These companies are: $A A A$ Auto Group NV Plc, listed on 26.09.2007, and Orco Property Group Plc, listed on 26.09.2007.

(source: http://www.bse.hu/topmenu/issuers/recentlisting/recent_listings.html)

${ }^{5}$ Source of data: eIFRS provided by IASB (http://eifrs.iasb.org/eifrs/) 
$d_{i}^{I F R S 3}=$ item $i$ according to IFRS $3 ; i=\overline{1 ; n_{I F R S 3}} ; n_{I F R S 3} \leq 47$;

$n_{\text {IFRS } 3}=$ total possible disclosure items according to IFRS 3 applied for the company, the maximum

value of which is 47 (in case of IFRS 3 Business Combinations);

$d_{i}^{\text {IAS27 }}=$ item $i$ according to IAS $27 ; i=\overline{1 ; n_{\text {IAS } 27}} ; n_{\text {IAS } 27} \leq 6$;

$d_{i}^{\text {IAS28 }}=$ item $i$ according to IAS $28 ; i=\overline{1 ; n_{\text {IAS } 28}} ; n_{\text {IAS } 28} \leq 16$;

$d_{i}^{\text {IAS31 }}=$ item $i$ according to IAS $31 ; i=\overline{1 ; n_{I A S 31}} ; n_{\text {IAS } 31} \leq 10$;

each $d$ item taking the value of 1 if the information is disclosed and 0 otherwise.

Dependent variables employed by the study are:

- Company size, measured as natural logarithm of assets and natural logarithm of sales;

- Profitability defined as return on equity (ROE): net income / shareholders' equity;

- Leverage or debt to equity ratio, computed as total liabilities / shareholders' equity;

- Auditor type, a dummy variable, being 1 if the auditor is a Big 4+2 company and 0 otherwise;

- Listing status designed to capture the cross listings and their potential implication on disclosure level: 1 if the company is listed on other (foreign) stock market(s) and 0 otherwise;

- International visibility as percentage of foreign sales (exports) in total sales;

- Type of industry, which is expressed as more dummy variables.

The econometric model used in the research is a multivariate linear model:

$$
\begin{aligned}
\text { Index }= & \alpha_{0}+\alpha_{1} \text { Size }+\alpha_{2} \text { Profitability }+\alpha_{3} \text { Leverage }+\alpha_{4} \text { AuditorType }+\alpha_{5} \text { ListingStatus }+ \\
& \alpha_{6} \text { InternationalVisibility }+\alpha_{7} \text { IndustryType }+\varepsilon
\end{aligned}
$$

and in a more technical form:

$$
\begin{gathered}
D I=\alpha_{0}+\alpha_{1} \ln (S)+\alpha_{2} \ln (T A)+\alpha_{3} R O E+\alpha_{4} \text { EPS }+\alpha_{5} \text { Lev }+\alpha_{6} \text { Aud }+\alpha_{7} \text { List }+\alpha_{8} \text { Visib }+ \\
\alpha_{9} \text { Chem }+\alpha_{10} \text { Ind }+\alpha_{11} \text { ITC }+\alpha_{12} \text { Trade }+\alpha_{13} \text { Serv }+\varepsilon
\end{gathered}
$$

where:

$D I=$ disclosure index, as defined in formula (2);

$S \quad=$ total sales;

$T A=$ total assets;

$R O E$ = return on equity;

$E P S=$ earnings per share (basic) in $\mathrm{Ft} /$ share;

Lev = leverage (debt to equity ratio);

Aud = auditor type;

List $=$ cross-country listing status;

Visib = international visibility;

Industry type: Chemical, Industrial, IT \& Communications, Trade and Services.

In testing the hypotheses we use the SPSS 14.0 for data processing purposes. The results and their discussion are based on the outputs generated by the software. 


\section{Discussion of the results}

As discussed earlier, the disclosure index is Achilles' heel of data management, therefore I detail this index in its components. As one can see the level of disclosure varies greatly from 0,25 (Állami Nyomda) to 1 (Magyar Telecom or MOL) together with the actual and possible disclosures within the standards.

Table no. 2

Dependent variable values and its components

\begin{tabular}{|c|c|c|c|c|c|c|c|c|c|}
\hline \multirow[t]{2}{*}{ Listed companies } & \multicolumn{2}{|c|}{$\begin{array}{c}\text { IFRS 3 } \\
\text { Business } \\
\text { combinations }\end{array}$} & \multicolumn{2}{|c|}{$\begin{array}{c}\text { IAS 27 } \\
\text { Consolidated and } \\
\text { Separate Financial } \\
\text { Statements }\end{array}$} & \multicolumn{2}{|c|}{$\begin{array}{c}\text { IAS 28 } \\
\text { Investments in } \\
\text { Associates }\end{array}$} & \multicolumn{2}{|c|}{$\begin{array}{c}\text { IAS 31 } \\
\text { Interests in Joint } \\
\text { Ventures }\end{array}$} & \multirow[t]{2}{*}{$\begin{array}{l}\text { Disclosure } \\
\text { Index } \\
\text { (DI) }\end{array}$} \\
\hline & Actual & Possible & Actual & Possible & Actual & Possible & Actual & Possible & \\
\hline AAA Auto Group & 11 & 19 & 2 & 2 & 0 & 0 & 0 & 0 & 0.6190 \\
\hline Állami Nyomda & 3 & 18 & 2 & 2 & 0 & 0 & 0 & 0 & 0.2500 \\
\hline Danubius Hotel \& Spa & 9 & 17 & 2 & 2 & 5 & 5 & 0 & 0 & 0.6667 \\
\hline econet.hu & 12 & 18 & 2 & 2 & 0 & 0 & 0 & 0 & 0.7000 \\
\hline EGIS & 4 & 17 & 3 & 3 & 5 & 5 & 0 & 0 & 0.4800 \\
\hline Fotex Public Co. & 10 & 17 & 2 & 2 & 0 & 0 & 0 & 0 & 0.6316 \\
\hline Gedeon Richter & 17 & 21 & 2 & 2 & 6 & 8 & 7 & 7 & 0.8421 \\
\hline Graphisoft Park SE & 3 & 10 & 0 & 0 & 0 & 0 & 0 & 0 & 0.3000 \\
\hline Magyar Telekom & 19 & 19 & 3 & 3 & 6 & 6 & 6 & 6 & 1 \\
\hline$M O L$ & 20 & 20 & 3 & 3 & 6 & 6 & 6 & 6 & 1 \\
\hline Orco Property & 5 & 17 & 2 & 2 & 4 & 4 & 6 & 6 & 0.5862 \\
\hline PannErgy & 9 & 18 & 3 & 4 & 2 & 6 & 0 & 0 & 0.5000 \\
\hline Phylaxia Pharma & 3 & 12 & 1 & 4 & 2 & 5 & 0 & 0 & 0.2857 \\
\hline Rába & 2 & 10 & 1 & 1 & 0 & 0 & 0 & 0 & 0.2727 \\
\hline Synergon & 18 & 21 & 4 & 4 & 0 & 0 & 0 & 0 & 0.8800 \\
\hline TVK & 15 & 21 & 4 & 4 & 6 & 6 & 0 & 0 & 0.8065 \\
\hline Zwack Unicum & 3 & 5 & 1 & 1 & 0 & 0 & 0 & 0 & 0.6667 \\
\hline
\end{tabular}

The table on the next page comprises a short statistical description of the variables used.

Table no. 3

Descriptive statistics of the variables

\begin{tabular}{lccclccc}
\hline Variable & Mean & $\begin{array}{c}\text { Std. } \\
\text { Deviation }\end{array}$ & $\mathrm{N}$ & Variable & Frequency & $\mathrm{N}$ \\
\hline & & & & & $\mathrm{n}=0$ & $\mathrm{n}=1$ & \\
\hline DI & 0.6169 & 0.2447 & 17 & Aud & 2 & 15 & 17 \\
$\ln (\mathrm{S})$ & 10.4383 & 2.3367 & & List & 13 & 4 & \\
$\ln (\mathrm{TA})$ & 10.7844 & 2.0046 & & Chem & & 5 & \\
ROE & 0.1352 & 0.1416 & & Ind & & 3 & \\
EPS & 881.56 & 1223.75 & & ITC & & 3 & \\
Lev & 0.8751 & 1.0873 & & Trade & & 2 & \\
Visib & 0.420 & 0.315 & & Serv & & 4 & \\
\hline
\end{tabular}

In order to test the previously specified hypotheses we use the stepwise method. The great advantage of the method is, that it optimizes the econometric model, so hat all (statistically) nonsignificant variables are eliminated from the model. Thus, the explanatory power of the model expressed by R-square (coefficient of determination) is maximum.

But before running the regression correlation between variables must be verified. Table 5 presents the results, together with their significance. As one can see from the second column, there are only few variables having acceptable correlation with the disclosure index (sales, total assets, 
foreign listing and being in the IT\&C industry), and there are even fewer that are significant - sales, total assets, and being in the IT\&C industry. Foreign listing, however, is not statistically significant.

This predicts that stepwise method will filter from our model many variables, as Table 4 confirms our conjecture.

\section{OLS regression model}

Model: $D I=-0.194+0.072 \cdot \ln (S)+0.309 \cdot I T C+\varepsilon$

\begin{tabular}{lccccc}
\hline \multicolumn{1}{c}{ Variables } & Beta & $\mathrm{t}$ & Signif. & $\begin{array}{c}\mathrm{F} \\
\text { (Signif.) }\end{array}$ & Adj. R $^{2}$ \\
\hline & & & & & \\
Included in the model & & & & \\
\hline constant & & -1.180 & 0.258 & 16.555 & 0.660 \\
$\ln (\mathrm{S})$ & 0.692 & 4.746 & 0.000 & $(0.000)$ & \\
ITC & 0.497 & 3.408 & 0.004 & & \\
& & & & & \\
Excluded from the model & & & & \\
\hline $\ln (\mathrm{TA})$ & 0.306 & 0.995 & 0.338 & & \\
ROE & -0.171 & -0.866 & 0.402 & & \\
EPS & 0.145 & 0.763 & 0.459 & & \\
Lev & -0.113 & -0.749 & 0.467 & & \\
Aud & -0.073 & -0.376 & 0.713 & & \\
List & 0.019 & 0.106 & 0.917 & & \\
Visib & -0.062 & -0.358 & 0.726 & & \\
Chem & 0.129 & 0.786 & 0.446 & & \\
Ind & -0.141 & -0.940 & 0.364 & \\
Trade & 0.082 & 0.542 & 0.597 & \\
Serv & -0.063 & -0.381 & 0.709 & & \\
\hline
\end{tabular}


Table no. 5

Correlation and collinearity matrix

\begin{tabular}{|c|c|c|c|c|c|c|c|c|c|c|c|c|c|c|}
\hline 2. $\ln (\mathrm{S})$ & $0.676^{* * *}$ & 1 & & & & & & & & & & & & \\
\hline 4. $\mathrm{ROE}$ & 0.206 & $0.621^{* *}$ & $0.445^{*}$ & 1 & & & & & & & & & & \\
\hline 5. EPS & 0.288 & $0.537^{*}$ & $0.645^{* *}$ & $0.369^{*}$ & 1 & & & & & & & & & \\
\hline 7. Aud & 0.191 & $0.562^{* *}$ & $0.555^{* *}$ & $0.599^{*}$ & 0.273 & 0.153 & 1 & & & & & & & \\
\hline 8. List & 0.431 & $0.527^{*}$ & $0.595^{* *}$ & 0.468 & 0.372 & $0.604^{* *}$ & 0.203 & 1 & & & & & & \\
\hline 9. Visib & $-0.043^{*}$ & 0.297 & 0.274 & 0.207 & 0.387 & $0.571^{* *}$ & 0.054 & $0.422^{*}$ & 1 & & & & & \\
\hline 10. Chem & 0.179 & 0.323 & 0.324 & -0.119 & $0.504^{*}$ & -0.252 & -0.165 & -0.054 & 0.359 & 1 & & & & \\
\hline 14. Serv & -0.388 & -0.301 & -0.064 & -0.084 & 0.063 & 0.064 & 0.203 & 0.019 & -0.130 & -0.358 & -0.257 & -0.257 & -0.203 & 1 \\
\hline
\end{tabular}

Explanation: variables were numbered; numbers in rows and columns represent the same variable.

Significance tests: ${ }^{*}$ significant on 0.05 level; ${ }^{* *}$ significant on 0.01 level; ${ }^{* * *}$ significant on 0.001 level. 
Our findings suggest that only sales and being in the IT\&C industry are associated on a statistically significant level with the level of disclosure. Therefore, only company size and industry type are associated with the extent of compliance with IFRS disclosure requirements, and hence the first and the last hypotheses can (should) be accepted.

We can also observe that the explanatory power of the model is acceptable Adj. $\mathrm{R}^{2}=0.660$, which means we can explain $66 \%$ of the variance of the disclosure index through company size and industry type. We consider somehow puzzling that our data did not validate other variables, furthermore, their significance level is very high, contrary to the findings of previous papers.

\section{Conclusions}

This contributes to our understanding in two ways. First of all this is the premier attempt to measure the level of IFRS disclosure compliance based on Hungarian data. Although it focuses only on the topic of consolidation, it provides evidence of significant non-compliance of the reporting entities - the average value of the disclosure index is $0.6169(62 \%)$. On the other hand, this study, based on previous literature, identified and tested factors that are associate with a certain level of compliance. Our evidence suggest, that only company size and industry type are associated with corporate compliance with IFRS.

These findings are in line with previous findings and confirm that only big companies can truly benefit from the 'blessing' of the application of IFRSs. It can also be concluded, that high tech industries, that are more resource eager also seem to comply better, possibly in order to maintain credibility, prestige and finally to be capable of raising more capital.

We consider that researching reporting practice in general, and IFRS disclosure compliance in special, contributes to understanding the true needs and problems of companies and, furthermore, their behavior towards (a) certain (set of) standards. These are the top challenges of our contemporary knowledge-based, profit oriented, risk aversive business environment.

\section{References}

1. Belkaoui, A. and Kahl, A. - Corporate financial disclosure in Canada. Vancouver: Research monograph of the Canadian Certified General Accountants Association, 1978.

2. Borbély, K. and Evans, L. - Accounting in Europe, 3, A matter of principle: Recent developments in Hungarian accounting thought and regulation, 2006, pp.135-68.

3. Buzby, S.L. (1975) Company Size, Listed Versus Unlisted Stocks, and the Extent of Financial Disclosure, Journal of Accounting Research, (Spring), 13(1), pp. 16-37.

4. Cairns, D. (1999) The FT International Accounting Standards Survey (London: Financial Times).

5. Cerf, R.A. (1961) Corporate reporting and investment decisions, Berkley, CA: University of California Press.

6. Chow, C.W. and Wong-Boren, A. (1987). Voluntary financial disclosure by Mexican corporations, The Accounting Review, 62 (3), pp. 533-541.

7. Cooke, T. E. (1989) Disclosure in the Corporate Annual Reports of Swedish Companies, Accounting and Business Research, 19(74), pp. 113-24.

8. Cooke, T. (1991). An assessment of voluntary disclosure in annual reports of Japanese corporations, International Journal of Accounting, 26 (3), pp. 174-189.

9. Cooke, T. E. (1992) The Impact of Size, Stock Market Listing and Industry Type on Disclosure in the Annual Reports of Japanese Listed Corporations, Accounting and Business Research, 22(87), pp. 229-37.

10. Cooke, T. E. (1998) Regression Analysis in Accounting Disclosure Studies, Accounting and Business Research, 28(3), pp. 209-24. 
11. Dahawy, K., Merino, B.D. and Conover, T.L. (2002) The conflict between IAS disclosure requirements and the secretive culture in Egypt, Advances in International Accounting, 15, pp. 203-28.

12. Daske, H., Hail, L., Leuz., C. and Verdi, R. (2008) Mandatory IFRS Reporting around the World: Early Evidence on the Economic Consequences, Journal of Accounting Research, 46(5), p. 1085-1142.

13. Debreceny, R. and Rahman, A. (2005) Firm-specific determinants of continuous corporate disclosures, International Journal of Accounting, 40, pp. 249-78.

14. Deloitte (2006) International Financial Reporting Standards Presentation and disclosure checklist, Iuly, available in electronic format on: http://www.iasplus.com/fs/2006checklist.pdf.

15. Dumontier, P. şi Raffournier, B. (1998) Why Firms Comply Voluntarily with IAS: An Empirical Analysis with Swiss Data, Journal of International Financial Management and Accounting, 9(3), pp. 216-45.

16. El-Gazzar, S.M., Finn, Ph.M. and Jacob, R. (1999) An Empirical Investigation of Multinational Firms' Compliance with International Accounting Standards, International Journal of Accounting, 34(2), pp. 239-48.

17. Fearnley, S. and Sunder, S. (2006) Global reporting standards: the Esperanto of accounting, Accountancy, 137(May), p. 26.

18. Fekete, Sz., Tiron-Tudor, A. and Muțiu, A. (2008) Determinants of the Comprehensiveness of Corporate Internet Reporting by Romanian Listed Companies, working paper presented in AMIS 2008 conference in Bucharest.

19. Fekete, Sz. (2008) Cercetare conceptuală şi empirică privind raportările financiare. Cazul sistemului contabil românesc şi maghiar [Conceptual and empirical research in financial reporting. The case of the Romanian and Hungarian accounting systems], Doctoral thesis, BabeşBolyai University of Cluj-Napoca, Faculty of Economics and Business Administration.

20. Glaum, M. and Street, D.L. (2003) Compliance with the Disclosure Requirements of Germany's New Market: IAS Versus US GAAP, Journal of International Financial Management and Accounting, 14(1), pp. 64-100.

21. Healy, P.M. and Palepu, K.G. (2001) Information asymmetry, corporate disclosure, and the capital markets: A review of the empirical disclosure literature, Journal of Accounting and Economics, 31, pp. 405-440.

22. Hope, O.-K., Jin, J. És Kang, T. (2006): Empirical Evidence on Jurisdictions that Adopt IFRS, Journal of International Accounting Research, 5(2), pp. 1-20.

23. Inchausti, B. (1997). The influence of company characteristics and accounting regulation on information disclosed by Spanish firms. European Accounting Review, 6(1), pp. 4568.

24. Joshi, P.L. and Al-Mudhahki, J. (2001) Empirical Study of Compliance with International Accounting Standards (IAS-1) by Stock Exchange Listed Companies in Bahrain, Journal of Financial Management and Analysis, 14(2), pp. 43-54.

25. Leuz, C. and Verrecchia, R.E. (2000) The Economic Consequences of Increased Disclosure, Journal of Accounting Research, 38, Supplement: Studies on Accounting Information and the Economics of the Firm, pp. 91-124.

26. Marston, C. and Polei, A. (2004) Corporate reporting on the Internet by German companies, International Journal of Accounting Information Systems, 5(3), pp. 285-311.

27. Meek, G. K., Roberts, C. B., and Gray, S. J. (1995). Factors influencing voluntary annual report disclosures by US, UK and Continental European multi-national corporations. Journal of International Business Studies, 26 (Third Quarter, 3), pp. 555-72. 
28. Oyelere, P. and Laswad, F. (2003) Determinants of Internet Financial Reporting by New Zealand Companies, Journal of International Financial Management and Accounting, 14(1), pp. 26.

29. Raffournier, B. (2003) The Determinants of Internet Financial Reporting by Swiss Companies, working paper presented at 26th Congress of the EAA, Seville (Spain).

30. Singhvi, S., and Desai, H. (1971). An empirical analysis of the quality of corporate financial disclosure. Accounting Review, January, 46 (1), 129-38.

31. Street, D.L. and Bryant, S.M. (2000) Disclosure Level and Compliance with IASs: A Comparison of Companies With and Without U.S. Listings and Filings, International Journal of Accounting, 35(3), pp. 305-29.

32. Street, D.L. and Gray, S.J. (2002) Factors influencing the extent of corporate compliance with International Accounting Standards: summary of a research monograph, Journal of International Accounting, Auditing and Taxation, 11, pp. 51-76.

33. Street, D.L., Gray, S.J., and Bryant, S.M. (1999). Acceptance and Observance of International Accounting Standards: An empirical study of companies claiming to comply with IASs. The International Journal of Accounting, 34 (1), pp. 11-48.

34. Taplin, R., Tower, G. and Hancock, Ph. (2002) Disclosure (discernibility) and compliance of accounting policies: Asia-Pacific evidence, Accounting Forum, 26(2), pp. 172-90.

35. Tower, G., Hancock, Ph. and Taplin, R.H (1999) A regional study of listed companies' compliance with international accounting standards. Preview, Accounting Forum, 23(3), pp. 293305.

36. Wallace, R.S.O. and Naser, K (1995) Firm-Specific Determinants of the Comprehensiveness of Mandatory Disclosure in the Corporate Annual Reports of Firms Listed on the Stock Exchange of Hong Kong., Journal of Accounting and Public Policy, 14(4), pp. 311-68.

37. Wallace, R.S.O., Naser, K. and Mora, A. (1994) The Relationship Between the Comprehensiveness of Corporate Annual Reports and Firm Characteristics in Spain, Accounting and Business Research, 25(97), pp. 41-53. 